\title{
Field observations on the behavioural ecology of the stout bobtail squid Rossia macrosoma (Cephalopoda: Sepiolidae) from Scottish waters
}

\author{
Christian Drerup ${ }^{1,2}\left(\right.$ D $\cdot$ Andy Jackson ${ }^{2} \cdot$ Chris Rickard $^{2} \cdot$ Mark Skea $^{2} \cdot$ Gavan M. Cooke $^{2}$
}

Received: 11 February 2021 / Revised: 26 March 2021 / Accepted: 6 May 2021 / Published online: 21 June 2021

(c) The Author(s) 2021

\begin{abstract}
Bobtail squids (Cephalopoda: Sepiolidae) are emerging model organisms for a wide range of genetic, anatomical, neurophysiological and behavioural studies. However, the knowledge about their behavioural ecology is scarce and derives mainly from laboratory-based studies, whereas observations from the wild are rare. Here, we use photo and video footage collected through the Cephalopod Citizen Science Project to describe the hunting, burying, mating and spawning behaviour of the stout bobtail squid Rossia macrosoma (Delle Chiaje, 1830) from Scottish waters. Based on our long-term observations, we were able to determine a spawning period from August to November based on different behavioural traits for this species. Furthermore, we observed $R$. macrosoma to be able to adhere a sand grain layer ('sand coat') to its dorsal mantle. This behavioural feature has only been reported for two genera of the sepiolid subfamily Sepiolinae so far, and therefore represents the first of this kind for the subfamily Rossiinae. Lastly, we identified a local sea urchin species as an active predator of egg batches of $R$. macrosoma and discussed the cryptic egg laying behaviour of this bobtail squid species in terms of its protective traits to avoid egg predation.
\end{abstract}

Keywords Citizen science $\cdot$ Egg predation $\cdot$ Reproductive behaviour $\cdot$ Sand coat $\cdot$ Spawning season

\section{Introduction}

Sepiolid cephalopods, commonly known as bobtail squids, occur circumglobally in tropical, temperate and polar waters. While members of the subfamily Heteroteuthinae exhibit an oceanic or pelagic lifestyle, the other two subfamilies Sepiolinae and Rossiinae can be considered predominantly benthic and are reported to inhabit the continental slope from intertidal waters to depths of more than $1600 \mathrm{~m}$ (Reid and Jereb 2005). Members of the latter two

Communicated by M. Vechione

Christian Drerup

cd731@cam.ac.uk

$\triangle$ Gavan M. Cooke

cephcitscience@gmail.com

1 Marine Behavioural Ecology Group, Department of Zoology, University of Cambridge, Downing St, Cambridge CB2 3EJ, UK

2 The Cephalopod Citizen Science Project, 138 Alder Road, Poole BH12 4AB, UK subfamilies have been reared and investigated in laboratory settings over the last few decades (e.g. Boletzky et al. 1971; Hanlon et al. 1997), and some of these species are now emerging model organisms for a range of biological studies (McAnulty and Nyholm 2017; Belcaid et al. 2019). Despite the strong interest in using these small-sized cephalopods for genetic (e.g. Belcaid et al. 2019), anatomical (e.g. Kerbl et al. 2013), neurophysiological (e.g. Howard et al. 2019) or behavioural studies (e.g. Drerup et al. 2020), the knowledge of their lifestyle and behavioural repertoires is still scarce. Most observations derive from less than 10 of the roughly 70 extant species and are commonly obtained from captive animals in the lab, whereas publications of wild bobtail squid behaviour are rare (Shimek 1983; Anderson 1987; Anderson and Mather 1996). However, understanding the behavioural ecology of bobtail squids is of great value as a reference for research studies, especially for those in which their behaviour will be experimentally manipulated. Moreover, a better comprehension of the behaviour of cephalopods is vital to establish good welfare practise when holding them in captive environments (Cooke et al. 2019; Ponte et al. 2019). 
As with all species of the subfamily Rossiinae, the stout bobtail squid Rossia macrosoma (Delle Chiaje, 1830) is associated with colder waters down to a depth of approximately $900 \mathrm{~m}$. Its distribution ranges from the Greenland Sea to the coast of Norway, the North Sea, the European and North-African Atlantic coastline and most parts of the Mediterranean Sea (Reid and Jereb 2005). This species has been examined in some detail in terms of its developmental biology (Boletzky and Boletzky 1973), anatomy and morphology (Jensen and Tjønneland 1977; Hou and Maxwell 1992; Wild et al. 2015) as well as its population ecology and reproductive systems (Rosa et al. 2006; Laptikhovsky et al. 2008; Salman and Önsoy 2010; Akalin et al. 2016). Its behavioural ecology, however, has only been sparsely investigated (Racovitza 1894; Mangold-Wirz 1963).

\section{Materials and methods}

Here, we report field observations of $R$. macrosoma from Scottish waters and compare those findings with existing reports from laboratory-based studies. All presented observations of $R$. macrosoma were collected through The Cephalopod Citizen Science Project (https://www.cephalopod citizenscience.com/), both pro- and retroactively. Video and photo material was obtained from SCUBA divers in different locations in Scottish waters, namely Loch Broom $\left(57^{\circ} 51^{\prime} 22.1^{\prime \prime} \mathrm{N}, 5^{\circ} 05^{\prime} 52.2^{\prime \prime} \mathrm{W}\right)$, Loch Ewe (57 $48^{\circ} 49.5^{\prime \prime}$ $\left.\mathrm{N}, 5^{\circ} 37^{\prime} 30.9^{\prime \prime} \mathrm{W}\right)$, Loch Carron ( $57^{\circ} 22^{\prime} 52.6^{\prime \prime} \mathrm{N}, 5^{\circ} 29^{\prime}$ $\left.50.8^{\prime \prime} \mathrm{W}\right)$, Loch Duich ( $\left.57^{\circ} 14^{\prime} 31.7^{\prime \prime} \mathrm{N}, 5^{\circ} 28^{\prime} 27.9^{\prime \prime} \mathrm{W}\right)$ and Loch Linnhe (56 $37^{\prime} 56.9^{\prime \prime} \mathrm{N}, 5^{\circ} 22^{\prime} 15.5^{\prime \prime} \mathrm{W}$ ) (Fig. 1). All footage used in this study was obtained during daytime in depths between 9 and $30 \mathrm{~m}$. The water temperature showed no spatial variation in between the lochs but ranged from 8 in January to $13{ }^{\circ} \mathrm{C}$ in September and October. The observations analysed for this study span from March 2011 until January 2021. Encountered individuals were identified as $R$. macrosoma by assessing morphological characteristics following Bello (1995) and Reid and Jereb (2005).

\section{Results and discussion}

A total of 7 hunting events were observed for R. macrosoma, all targeted at caridean shrimp species. Hunting attempts followed the common sequence for other bobtail squids and cuttlefish, namely attention, positioning and seizure (Messenger 1968). After visually noticing a shrimp, the observed individuals of $R$. macrosoma pointed their arms towards it while forming an elongated cone with the tips of the tentacles protruding from it (Fig. 2a). After slowly approaching the prey and reaching the desired attack distance (roughly one mantle length), the tentacles would

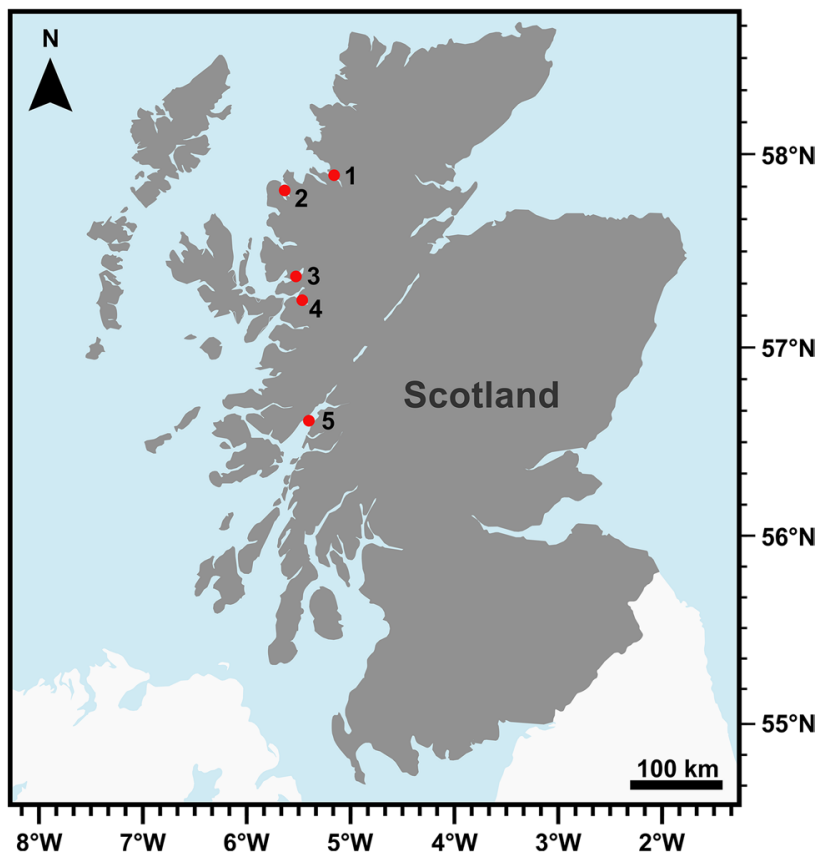

Fig. 1 Map of Scotland (excluding Orkney, Shetland, North Rona and Sula Sgeir) containing the survey sites of the present study, namely (1) Loch Broom, (2) Loch Ewe, (3) Loch Carron, (4) Loch Duich, (5) Loch Linnhe

shoot at the prey along with simultaneous lateral flinging of their arms (Fig. 2b). These observations follow the general hunting behaviour described for Rossia pacifica (Brocco, 1971) and other bobtail squids (e.g. Boletzky et al. 1971; Bergström 1985; Drerup et al. 2020). Of the 7 observed hunting events, the shrimp were caught three times by their carapax, whereas on the remaining 4 occasions, the bobtail squid missed the prey due to its rapid escape movements. If successfully seized, the prey was then pulled back into the buccal area of the bobtail squid (Fig. 2c), wrapped by the arms and subsequently moved for ingestion which occurred while resting on or hovering close to the bottom (Fig. 2d). All observed individuals maintained their dark body colouration throughout the entire hunting procedure. This is contrary to most other bobtail squids which either blanch (Brocco 1971; Bergström 1985) or exhibit a variety of colour patterns during hunting (Moynihan 1983; Mauris 1989).

While burying is a common feature for species of the subfamily Sepiolinae (Boletzky and Boletzky 1970; Rodrigues et al. 2010; Drerup et al. 2020), there is some debate about this behavioural aspect for species of the subfamily Rossiinae. While Summers and Colvin (1989) and Anderson et al. (2004) observed $R$. pacifica to bury in different sediment types, no such behaviour has been detected for the same species by Brocco (1971). According to Boletzky and Boletzky (1973), captive $R$. macrosoma rarely show burying activity and rather seek shelter under bivalve shells. From 

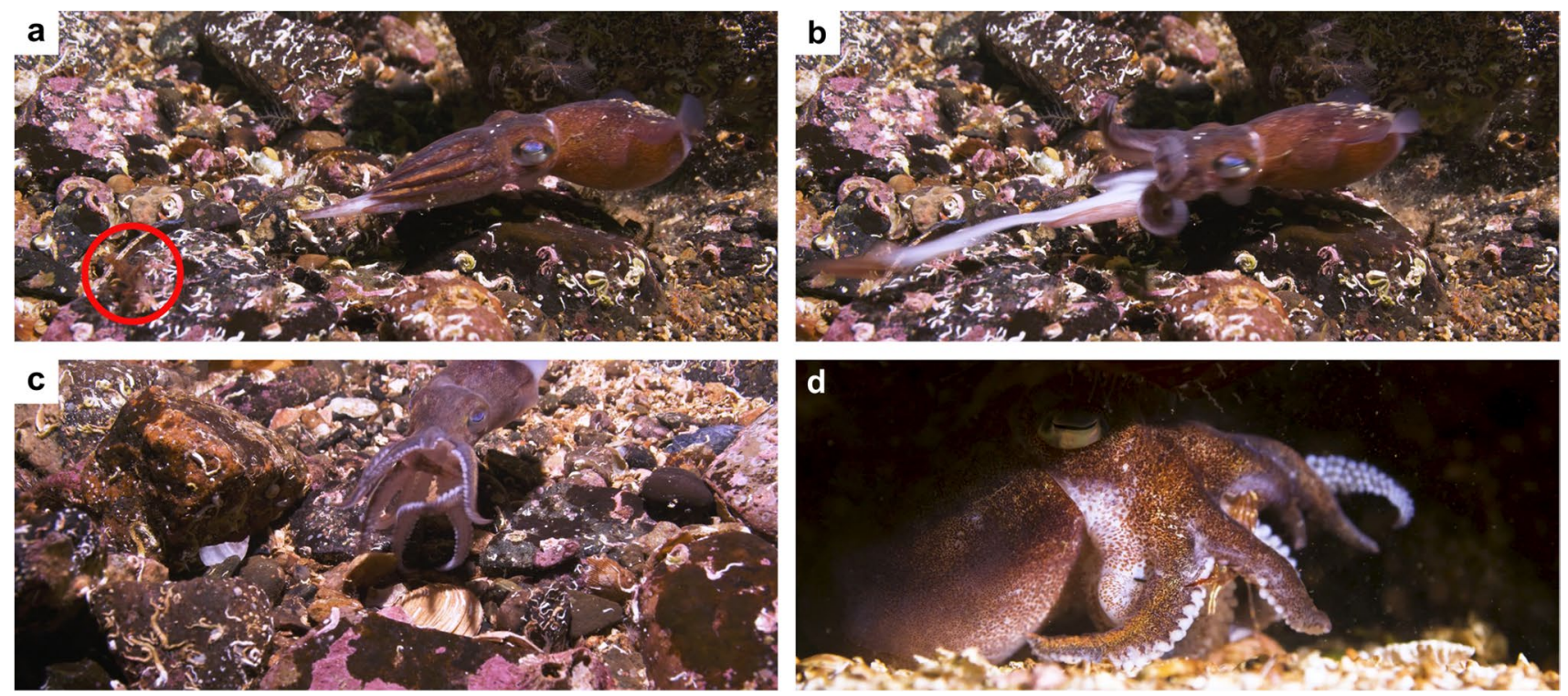

Fig. 2 Hunting behaviour in Rossia macrosoma; a Approach towards prey (caridean shrimp, marked by red circle) with arms formed to an elongated cone and the tips of the tentacles slightly protruding; $\mathbf{b}$ Seizure of prey by shooting the tentacles while simultaneously fling-

our observations, we can conclude that wild $R$. macrosoma both seek shelter in crevasses or under rocks and coral arms, as well as bury in the sediment (Fig. 3a, Supplementary Material Fig. S1). The burying sequence follows the common two-phased pattern described for $R$. pacifica (Anderson et al., 2004) and bobtail squid species of the subfamily Sepiolinae (Boletzky and Boletzky 1970; Anderson et al. 2002; Rodrigues et al. 2010; Drerup et al. 2020). In phase 1 , the observed individuals created a depression in the sediment by tilting their bodies slightly forward and ejecting a forward-directed funnel jet, followed by a stronger, backward-directed funnel jet to swirl up sediment. Further alternating forward- and backward-directed funnel jets were performed to disperse more sediment in the water column

ing the arms open; $\mathbf{c}$ Retraction of successfully captured prey into the buccal area of $R$. macrosoma; $\mathbf{d}$ Wrapping of prey item with the arms and positioning it for subsequent ingestion; a-d All photos taken as still images from video material captured by Andy Jackson

and increase the depth of the depression. During this process, the sepiolids immersed their body in the depression, whereas their dorsal body half got covered by the descending sediment particles. In the subsequent second phase, the dorsolateral arm pair was raised and sediment from the vicinity of the sepiolids was gathered by synchronous sweeping arm movements.

Occasionally, individuals of $R$. macrosoma emerging from the sediment were observed to keep their dorsal body site covered with a layer of sediment particles (Fig. 3). This so-called sand coat (sensu Singley 1982) has so far only been observed in two genera of the subfamily Sepiolinae (e.g. Singley 1982, 1983; Shears 1988; Nabhitabhata et al. 2005; Drerup et al. 2020). Therefore, our observations
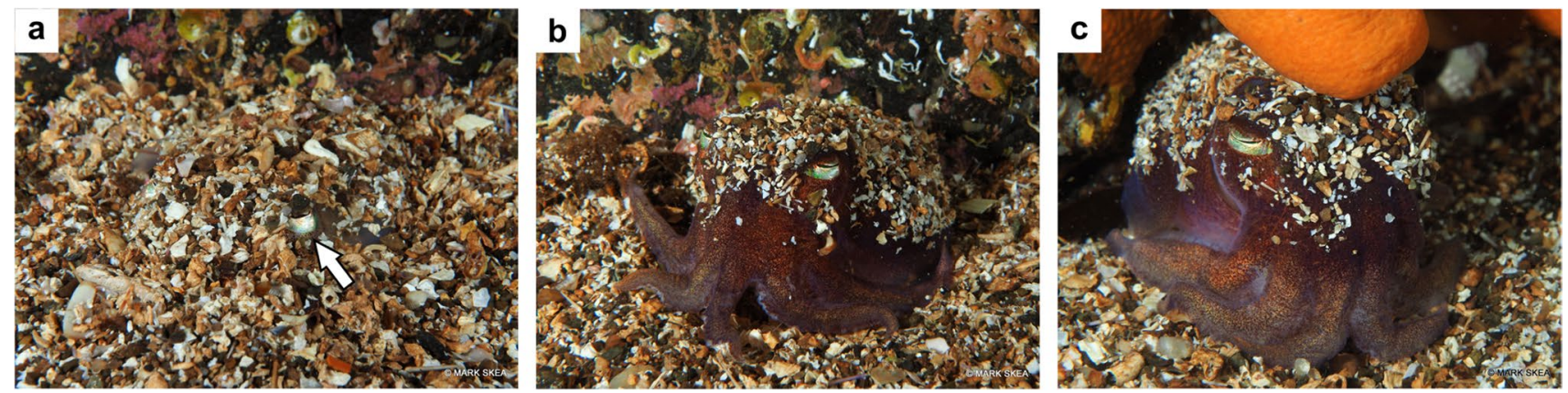

Fig. 3 Sand coating behaviour in Rossia macrosoma; a Buried individual, with the eyes (left eye indicated by arrow) uncovered; b-c The same individual wearing a layer of sediment particles ('sand coat') b immediately after emerging from the sediment as well as c after moving to a sheltering overhang. a-c All photos taken by Mark Skea 
Fig. 4 Mating behaviour in Rossia macrosoma; a-b Mating couple, with the male holding the female in the 'maleto-female neck' position; c-f Female individuals with spermatangia attached $\mathbf{c}$ centrally on the head (red circle); d close to the opening of the oviduct (red circle), and e to their dorsal head-mantle region (red rectangle), with $\mathbf{f}$ being a close-up of the highlighted area; a-f All photos taken by Mark Skea (a-b as still images from video material)
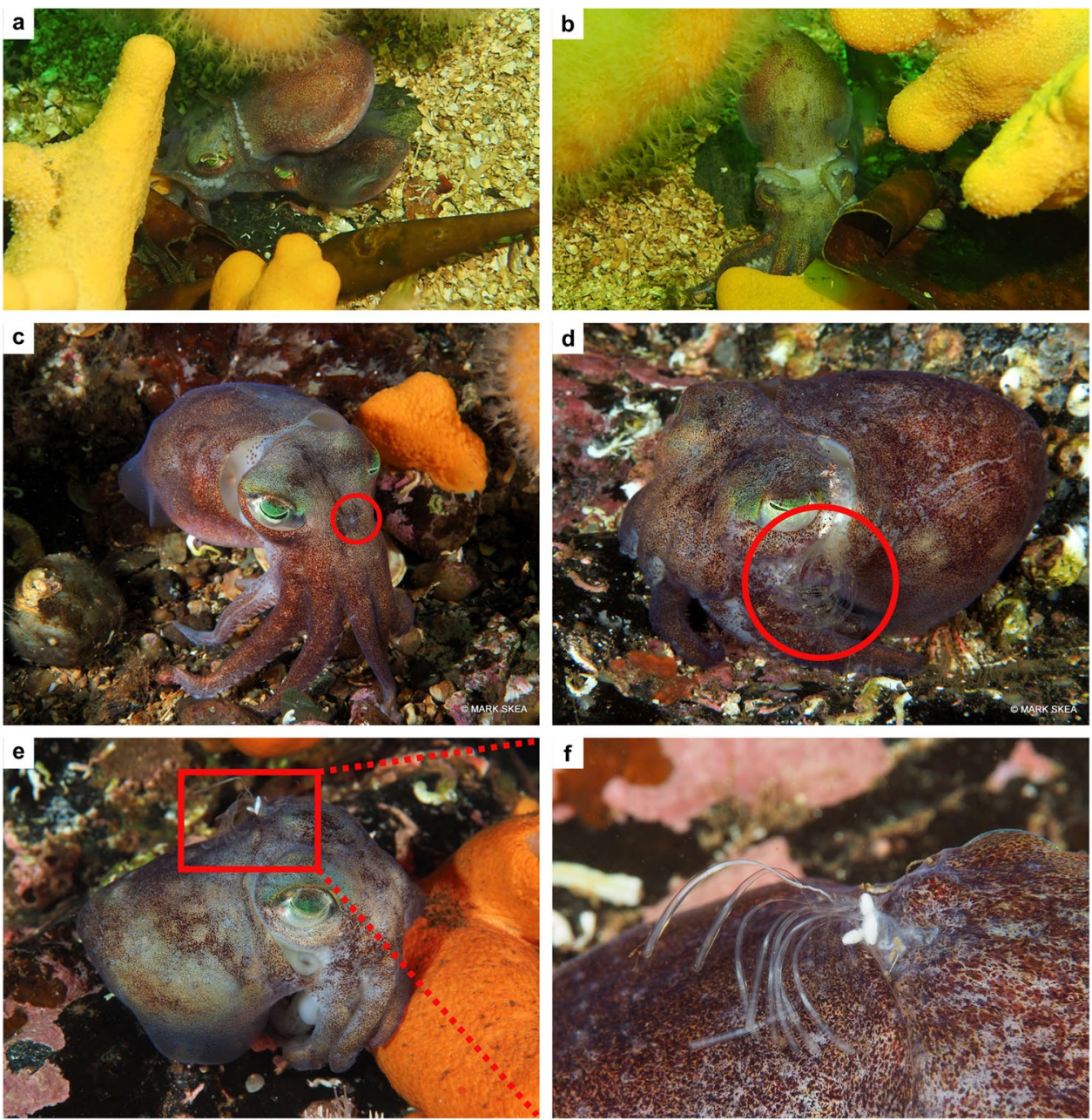

represent the first of this kind for the subfamily Rossiinae. In the subfamily Sepiolinae, these sand coats adhere due to the secretions of two different gland types in the dorsal epidermis (von Byern et al. 2017) and are presumably used as cryptic camouflage (Singley 1982; Shears 1988). While the purpose of this behavioural feature is probably the same in $R$. macrosoma, the exact nature of how the sediment adheres to, and is released from the sepiolid's body, needs to be addressed in future studies.

One mating event was observed for R. macrosoma in July 2020. As the copulation started before the approach of the divers and continued beyond the end of recording (total length 5:28 $\mathrm{min}$ ), the total duration of this event cannot be stated. Nevertheless, mating occurred in the 'male-to-female neck' position, and the couple remained moderately motionless on the sediment for the length of recording (Fig. 4a-b). Therefore, the mating behaviour of wild $R$. macrosoma is similar to that of captive individuals of this species (Racovitza 1894; Mangold-Wirz 1963), as well as to R. pacifica (Brocco 1971) and most species of the subfamily Sepiolinae (Nabhitabhata et al. 2005; Rodrigues et al. 2009; Squires et al. 2013).
In the genera Euprymna, Sepietta and Sepiola, the male transfers spermatophores to the female's bursa copulatrix

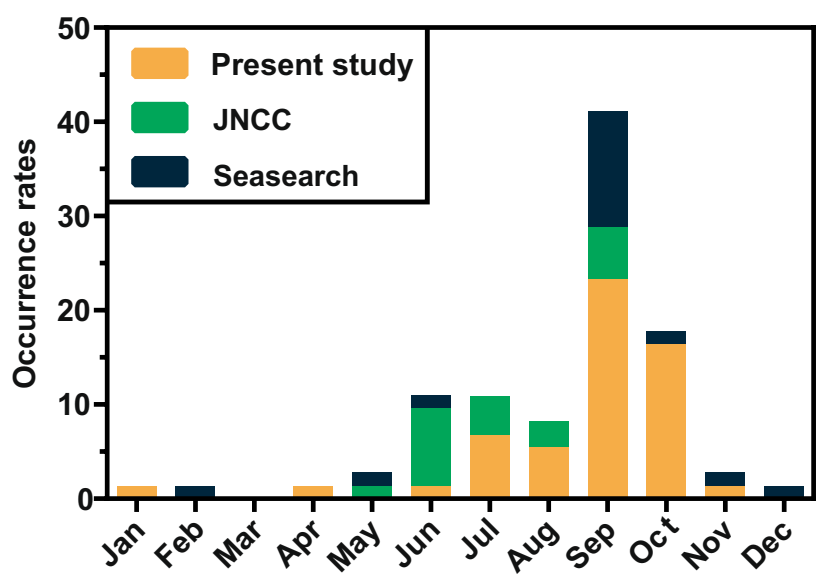

Fig. 5 Occurrence rates of reported individuals of $R$. macrosoma in West Scottish waters. Presented are the occurrence rates from the present study (obtained through the Cephalopod Citizen Science Project) as well as from the data sets of the Joint Nature Conservation Committee (2018) and Seasearch (2020) 
(summarised in Hoving et al. 2008), a pouch-like structure in the mantle cavity close to the genital opening that can store spermatophores for up to 145 days (Squires et al. 2014). In the subfamily Rossiinae, however, males have been reported to implant several spermatangia either to the females' body and mantle tissue or a ridged area near the opening of the oviduct on the left side of their body (Zumholz and Frandsen 2006; Cuccu et al. 2007; Hoving et al. 2009). This behaviour has recently also been shown in $R$. macrosoma by Akalin et al. (2016). Our findings can confirm spermatophore implantation in this species as on four occasions between July and November 2020 we observed female $R$. macrosoma
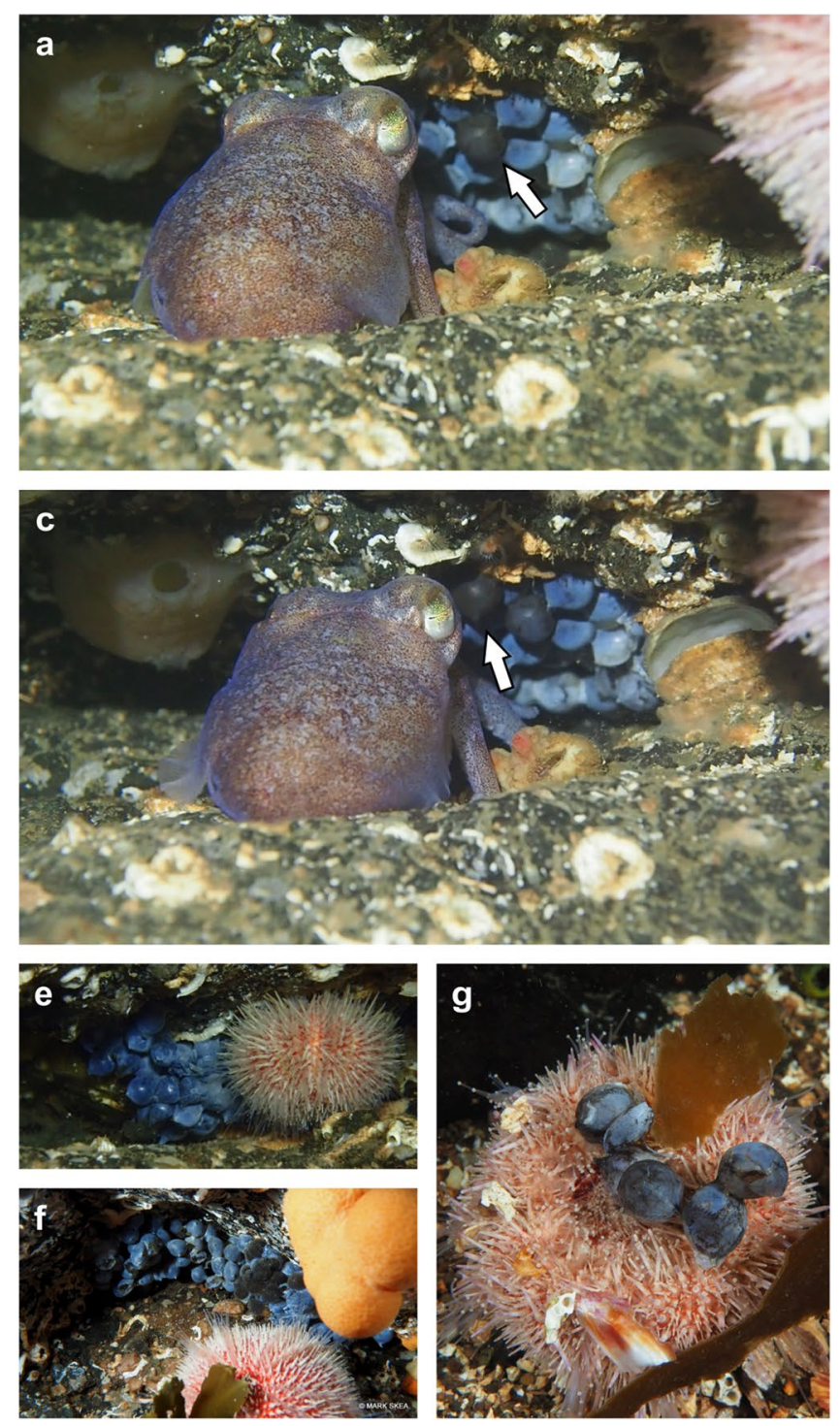

Fig. 6 Spawning behaviour of Rossia macrosoma; a-c Sequence of spawning event; a After spawning one egg (marked with arrow) onto an already existing egg batch, the female rests in preparation for the next egg; b The female clings with its arms to the substrate and spawns another egg; c New resting period. The previously spawned egg is indicated with an arrow; d Batch of freshly spawned eggs with spermatangia attached centrally on the head, along their dorsal head-mantle region, or close to the opening of the oviduct on the left body side (Fig. 4c-f).

While the spawning period of $R$. macrosoma in the Mediterranean Sea presumably extends from March to November (Mangold-Wirz 1963), our long-term observations indicate a spawning period in West Scottish waters between August and November. Although our proposed spawning period is solely based on observations from SCUBA divers rather than an analysis of the sepiolids internal reproductive organs, it follows the general idea that $R$. macrosoma prefers deeper waters but seasonally migrates to shallower habitats (e.g. our
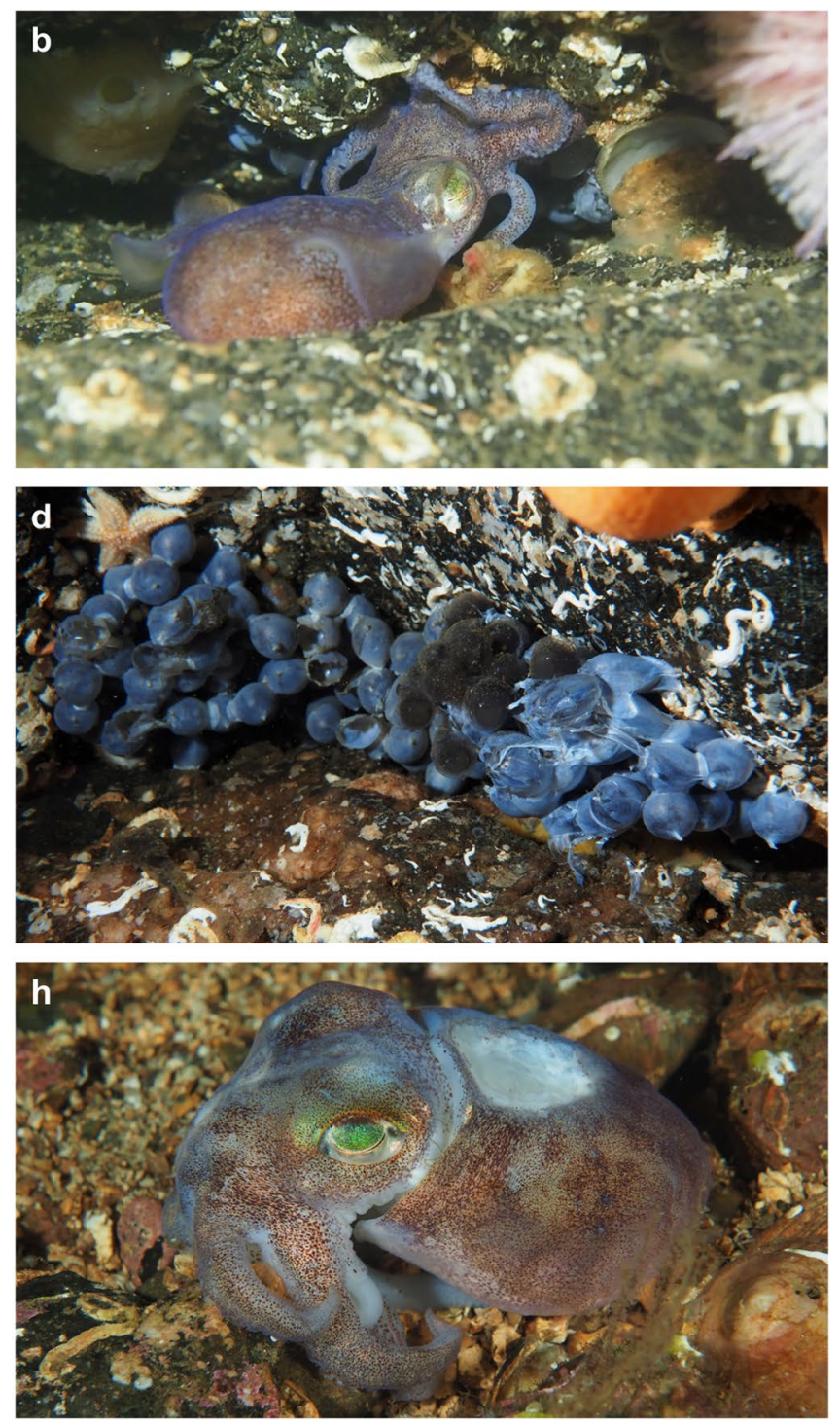

attached to a batch of older eggs; e-f Presence of the sea urchin Echinus esculentus at different egg batches of $R$. macrosoma; $\mathbf{g}$ Upsidedown sea urchin predating on eggs; $\mathbf{h}$ Individual showing signs of senescence on its dorsal mantle; $\mathbf{a}-\mathbf{d}, \mathbf{f}-\mathbf{h}$ Photos taken by Mark Skea (a-c as still images from video material); e Photo taken by Chris Rickard 
surveyed lochs in West Scotland with individuals frequently encountered between 9 and $30 \mathrm{~m}$ ) to mate and spawn (Reid and Jereb 2005). This is further supported by approximately 95\% of R. macrosoma individuals reported in this study that were encountered between June and November (with a prominent peak in September and October) (Fig. 5), despite year-round diving surveys in West Scottish waters. Similar occurrence rates ( 90 and $82 \%$, respectively) of $R$. macrosoma in these waters for the same timeframe can be calculated from the data sets provided by the Joint Nature Conservation Committee (2018) and Seasearch (2020). Taking all three data sets into account, we can state for $R$. macrosoma an occurrence rate of $92 \%$ in West Scottish waters between June and November (Fig. 5).

During spawning, females were observed to cling to the chosen substrate with their arms (Fig. 6b) but de-attached themselves periodically to rest in front of the egg batches (Fig. 6a, c). Freshly laid eggs were soft and black in colour but became to some extent rigid and blue over time (Fig. 6a-d). All observed egg batches consisted of several layers of eggs (Fig. 6a, c-f), as commonly observed in $R$. macrosoma (Racovitza, 1894; Boletzky \& Boletzky, 1973), R. pacifica (Summers \& Colvin, 1989; Anderson \& Shimek, 1994) and some other bobtail squid species (Nabhitabhata et al. 2005; Rodrigues et al. 2011). Our findings show that females frequently deposit their eggs on already existing egg batches (Fig. 6a-d). As R. macrosoma is an intermittent spawner (Salman and Önsoy 2010), like other sepiolin species (e.g. Gabel-Deickert 1995; Bello and Deickert 2003; Salman and Önsoy 2010; Salman 2011), it is possible that females return to a previous egg batch to continue spawning. However, it was not possible to determine if, in our observations, already existing egg batches were laid by the same female or derived from a conspecific.

Egg masses of $R$. macrosoma were commonly found in rock crevices or below overhangs (Fig. 6a-f). Bobtail squids commonly attach their eggs in cryptic places (e.g. Singley 1983; Summers and Colvin 1989; Drerup et al. 2020), presumably to avoid detection by predators. While we agree with this premise, we suggest that these narrow crevices are also chosen to physically prevent predators from reaching the eggs. This assertion is supported by the presence of sea urchins, presumably Echinus esculentus, along crevices containing eggs of $R$. macrosoma (Fig. 6e-g). Although most sea urchins are considered herbivorous, some species exhibit an omnivorous or even carnivorous diet (Baumiller 2008; Crook and Davoren 2016), and three species have been shown to prey upon cephalopods eggs (Martins et al. 2018). While in narrow crevices these predators are restrained from getting to sepiolids eggs due to their physical size, we have evidence that if the eggs are accessible, they will be preyed upon by sea urchins (Fig. 6g).
As with most cephalopod species, bobtail squids die shortly after their spawning period, and spent individuals can easily be identified by signs of senescence on their body (Roumbedakis and Guerra 2019). We observed individuals of $R$. macrosoma with clear indications of senescence (Fig. 6h) from August to December. These observations therefore support our estimated spawning period of $R$. macrosoma from approximately August to November.

In conclusion, the behavioural ecology of wild $R$. macrosoma matches observations of captive individuals of this and other species of the genus Rossia. Our study presents the first field observations of $R$. macrosoma outside the Mediterranean Sea and has revealed a so far unobserved behavioural feature for this genus, the ability to adhere a sand coat to its dorsal epidermis. This observation in particular promotes the need for additional studies on both wild and captive bobtail squids to understand their behavioural repertoires in detail. Considering bobtail squids as emerging model organisms, further laboratory studies on their behavioural ecology are likely to be published over the next few years. However, as field research is often expensive and time-consuming, our study has shown that citizen science is a valuable and cost-effective tool to obtain qualitative observations of wild cephalopod behaviour.

Supplementary Information The online version contains supplementary material available at https://doi.org/10.1007/s12526-021-01202-y.

Acknowledgements The authors would like to thank the two anonymous reviewers for their constructive comments.

\section{Declarations}

Conflict of interest The authors declare no competing interests.

Ethical approval No animal testing was performed during this study.

Sampling and field studies All necessary permits for sampling and observational field studies have been obtained by the authors from the competent authorities and are mentioned in the acknowledgements, if applicable. The study is compliant with CBD and Nagoya protocols.

Data availability All data generated or analysed during this study are included in this published article and its supplementary information files.

Authors' contribution $\mathrm{CD}$ and GMC conceived the study. AJ, CR and MS conducted the fieldwork and provided the footage. CD and GMC analysed the footage. CD wrote the first draft of the manuscript, and all authors read, commented and approved the final manuscript.

Open Access This article is licensed under a Creative Commons Attribution 4.0 International License, which permits use, sharing, adaptation, distribution and reproduction in any medium or format, as long as you give appropriate credit to the original author(s) and the source, provide a link to the Creative Commons licence, and indicate if changes were made. The images or other third party material in this article are included in the article's Creative Commons licence, unless indicated 
otherwise in a credit line to the material. If material is not included in the article's Creative Commons licence and your intended use is not permitted by statutory regulation or exceeds the permitted use, you will need to obtain permission directly from the copyright holder. To view a copy of this licence, visit http://creativecommons.org/licenses/by/4.0/.

\section{References}

Akalin M, Salman A, Önsoy B (2016) On the spermatophore implantation in bobtail squid Rossia macrosoma (Cephalopoda: Mollusca). J Black Sea/Mediterr Environ 22:250-258

Anderson RC (1987) Field aspects of the sepiolid squid Rossia pacifica Berry, 1911. West Soc Malacol Ann Rep 20:30-32

Anderson RC, Shimek R (1994) Field observations of Rossia pacifica (Berry, 1911) egg masses. Veliger 37:117-119

Anderson RC, Mather JA (1996) Escape responses of Euprymna scolopes Berry, 1911 (Cephalopoda: Sepiolidae). J Molluscan Stud 62:543-545

Anderson RC, Mather J, Steele C (2002) The burying behavior of the sepiolid squid Euprymna scolopes Berry, 1913 (Cephalopoda, Sepiolidae). West Soc Malacol Ann Rep 33:1-7

Anderson RC, Mather J, Steele C (2004) Burying and associated behaviors of Rossia pacifica (Cephalopoda: Sepiolidae). Vie Milieu 54:13-20

Baumiller TK (2008) Crinoid ecological morphology. Annu Rev Earth Planet Sci 36:221-249

Belcaid M, Casaburi G, McAnulty SJ, Schmidbaur H, Suria AM, Moriano-Gutierrez S, Pankey MS, Oakley TH, Kremer N, Koch EJ, Collins AJ, Nguyen H, Lek S, Goncharenko-Foster I, Minx P, Sodergren E, Weinstock G, Rokhsar DS, McFall-Ngai M, Simakov O, Foster JS, Nyholm SV (2019) Symbiotic organs shaped by distinct modes of genome evolution in cephalopods. Proc Natl Acad Sci 116:3030-3035

Bello G (1995) A key for the identification of the Mediterranean sepiolids (Mollusca: Cephalopoda). Bull Inst Oceanogr Monaco 16:41-56

Bello G, Deickert A (2003) Multiple spawning and spawning batch size in Sepietta oweniana (Cephalopoda: Sepiolidae). Cah Biol Mar 44:307-314

Bergström BI (1985) Aspects of natural foraging by Sepietta oweniana (Mollusca, Cephalopoda). Ophelia 24:65-74

Boletzky SV, Boletzky MVV (1970) Das Eingraben in Sand bei Sepiola und Sepietta (Mollusca, Cephalopoda). Rev Suisse Zool 77:536-548

Boletzky SV, Boletzky MVV (1973) Observations on the embryonic and early post-embryonic development of Rossia macrosoma (Mollusca, Cephalopoda). Helgol Wiss Meeresunters 25:135-161

Boletzky SV, Boletzky MVV, Frösch D, Gätzi V (1971) Laboratory rearing of Sepiolinae (Mollusca: Cephalopoda). Mar Biol 8:82-87

Brocco S (1971) Aspects of the biology of the sepiolid squid Rossia pacifica Berry. University of Victoria, Canada. MSc thesis

Crook KA, Davoren GK (2016) Influence of spawning capelin Mallotus villosus on the distribution of green sea urchins Strongylocentrotus droebachiensis on the northeast Newfoundland coast. Mar Ecol Prog Ser 549:125-135

Cooke GM, Tonkins BM, Mather JA (2019) Care and Enrichment for Captive Cephalopods. In: Carere C, Mather J (eds) The Welfare of Invertebrate Animals. Springer International Publishing, Cham, pp 179-208

Cuccu D, Mereu M, Cannas R, Follesa MC, Cau A, Jereb P (2007) Egg clutch, sperm reservoirs and fecundity of Neorossia caroli (Cephalopoda: Sepiolidae) from the southern Sardinian sea (western Mediterranean). J Mar Biol Assoc UK 87:971-976
Drerup C, Sykes AV, Cooke GM (2020) Behavioural aspects of the spotty bobtail squid Euprymna parva (Cephalopoda: Sepiolidae). J Exp Mar Biol Ecol 530-531:151442

Gabel-Deickert A (1995) Reproductive patterns in Sepiola affinis and other Sepiolidae (Mollusca, Cephalopoda). Bull Inst Oceanogr Monaco 16:73-83

Hanlon RT, Claes MF, Ashcraft SE, Dunlap PV (1997) Laboratory culture of the sepiolid squid Euprymna scolopes: a model system for bacteria-animal symbiosis. Biol Bull 192:364-374

Hou ST, Maxwell WL (1992) Evidence for an intermediate type of spermatozoon: ultrastructural studies of spermiogenesis in the cuttlefish Rossia macrosoma (Cephalopoda, Decabrachia). Zoomorphology 112:207-215

Hoving H, Laptikhovsky V, Piatkowski U, Önsoy B (2008) Reproduction in Heteroteuthis dispar (Rüppell, 1844) (Mollusca: Cephalopoda): a sepiolid reproductive adaptation to an oceanic lifestyle. Mar Biol 154:219-230

Hoving HJT, Nauwelaerts S, Van Genne B, Stamhuis EJ, Zumholz K (2009) Spermatophore implantation in Rossia moelleri Steenstrup, 1856 (Sepiolidae; Cephalopoda). J Exp Mar Biol Ecol 372:75-81

Howard RB, Lopes LN, Lardie CR, Perez PP, Crook RJ (2019) Earlylife injury produces lifelong neural hyperexcitability, cognitive deficit and altered defensive behaviour in the squid Euprymna scolopes. Philos Trans R Soc B 374:20190281

Joint Nature Conservation Committee (2018) Marine Nature Conservation Review (MNCR) and associated benthic marine data held and managed by JNCC. Occurrence dataset, accessed via GBIF.org on 2021-01-20. https://doi.org/10.15468/kcx3ca

Jensen H, Tjønneland A (1977) Ultrastructure of the heart muscle cells of the cuttlefish Rossia macrosoma (Delle Chiaje) (Mollusca: Cephalopoda). Cell Tissue Res 185:147-158

Kerbl A, Handschuh S, Nödl M-T, Metscher B, Walzl M, Wanninger A (2013) Micro-CT in cephalopod research: Investigating the internal anatomy of a sepiolid squid using a non-destructive technique with special focus on the ganglionic system. J Exp Mar Biol Ecol 447:140-148

Laptikhovsky V, Nigmatullin CM, Hoving H, Onsoy B, Salman A, Zumholz K, Shevtsov G (2008) Reproductive strategies in female polar and deep-sea bobtail squid genera Rossia and Neorossia (Cephalopoda: Sepiolidae). Polar Biol 31:1499-1507

Mangold-Wirz K (1963) Biologie des cephalopodes bentiques et nectoniques de la Mer Catalan. Vie Milieu 13:1-285

Martins CPP, Fernández-Álvarez FÁ, Villanueva R (2018) Invertebrate predation on egg masses of the European cuttlefish, Sepia officinalis: an experimental approach. Estuar Coast Shelf Sci 200:437-448

Mauris E (1989) Colour patterns and body postures related to prey capture in Sepiola affinis (Mollusca: Cephalopoda). Mar Freshwat Behav Physiol 14:189-200

McAnulty SJ, Nyholm SV (2017) The role of hemocytes in the Hawaiian bobtail squid, Euprymna scolopes: a model organism for studying beneficial host-microbe interactions. Front Microbiol 7:2013

Messenger JB (1968) The visual attack of the cuttlefish, Sepia officinalis. Anim Behav 16:342-357

Moynihan M (1983) Notes on the behavior of Euprymna scolopes (Cephalopoda: Sepiolidae). Behaviour 85:25-41

Nabhitabhata J, Nilaphat P, Promboon P, Jaroongpattananon C (2005) Life cycle of cultured bobtail squid, Euprymna hyllebergi Nateewathana, 1997. Phuket Mar Biol Cent Res Bull 66:351-365

Ponte G, Andrews P, Galligioni V, Pereira J, Fiorito G (2019) Cephalopod welfare, biological and regulatory aspects: an EU experience. In: Carere C, Mather J (eds) The Welfare of Invertebrate Animals. Springer International Publishing, Cham, pp 209-228

Racovitza EG (1894) Sur l'accouplement de quelques Céphalopodes, Sepiola Rondeletii (Leach), Rossia macrosoma (d. Ch.) et Octopus vulgaris (Lam.). Gauthier-Villars et fils 
Reid A, Jereb P (2005) Family Sepiolidae. In: Jereb P, Roper CF (eds) Cephalopods of the World. an Annotated and Illustrated Catalogue of Cephalopod Species Known to Date. Volume 1. Chambered Nautiluses and Sepioids (Nautilidae, Sepiidae, Sepiadariidae, Idiosepiidae and Spirulidae). FAO, Rome, pp 153-212

Rodrigues M, Garci ME, Guerra Á, Troncoso JS (2009) Mating behavior of the Atlantic bobtail squid Sepiola atlantica (Cephalopoda: Sepiolidae). Vie Milieu 59:271-275

Rodrigues M, Garci ME, Troncoso JS, Guerra A (2010) Burying behaviour in the bobtail squid Sepiola atlantica (Cephalopoda: Sepiolidae). Ital J Zool 77:247-251

Rodrigues M, Garcí ME, Troncoso JS, Guerra Á (2011) Spawning strategy in Atlantic bobtail squid Sepiola atlantica (Cephalopoda: Sepiolidae). Helgol Mar Res 65:43-49

Rosa R, Pereira J, Costa P, Nunes M (2006) Distribution, abundance, biology and biochemistry of the stout bobtail squid Rossia macrosoma from the Portuguese coast and. Mar Biol Res 2:14-23

Roumbedakis K, Guerra Á (2019) Cephalopod Senescence and Parasitology. In: Gestal C, Pascual S, Guerra Á, Fiorito G, Vieites JM (eds) Handbook of Pathogens and Diseases in Cephalopods. Springer International Publishing, Cham, pp 207-211

Salman A (2011) Reproductive biology of Neorossia caroli (Cephalopoda: Sepiolidae) in the Aegean Sea. Sci Mar 75:9-15

Salman A, Önsoy B (2010) Reproductive biology of the bobtail squid Rossia macrosoma (Cephalopoda: Sepiolidea) from the eastern Mediterranean. Turkish J Fish Aquat Sci 10:81-86

Seasearch (2020) Seasearch Marine Surveys in Scotland. Occurrence dataset, accessed via GBIF.org on 2021-01-20. https://doi.org/ 10.15468/0hyjxi
Shears J (1988) The use of a sand-coat in relation to feeding and diel activity in the sepiolid squid Euprymna scolopes. Malacologia 29:121-133

Shimek R (1983) Escape behavior of Rossia pacifica Berry, 1911. Am Malacol Bull 2:91-92

Singley C (1982) Histochemistry and fine-structure of the ectodermal epithelium of the sepiolid squid Euprymna scolopes. Malacologia 23:177-192

Singley C (1983) Euprymna scolopes. In: Boyle PR (ed) Cephalopod Life Cycles, Vol. I: Species Accounts. Academic, London, pp 69-74

Squires ZE, Norman MD, Stuart-Fox D (2013) Mating behaviour and general spawning patterns of the southern dumpling squid Euprymna tasmanica (Sepiolidae): a laboratory study. J Molluscan Stud 79:263-269

Squires ZE, Wong BB, Norman MD, Stuart-Fox D (2014) Multiple paternity but no evidence of biased sperm use in female dumpling squid Euprymna tasmanica. Mar Ecol Prog Ser 511:93-103

Summers WC, Colvin L (1989) On the cultivation of Rossia pacifica (Berry, 1911). J Cephalopod Biol 1:21-32

von Byern J, Cyran N, Klepal W, Nödl MT, Klinger L (2017) Characterization of the adhesive dermal secretion of Euprymna scolopes Berry, 1913 (Cephalopoda). Zoology 120:73-82

Wild E, Wollesen T, Haszprunar G, Heß M (2015) Comparative 3D microanatomy and histology of the eyes and central nervous systems in coleoid cephalopod hatchlings. Org Divers Evol 15:37-64

Zumholz K, Frandsen RP (2006) New information on the life history of cephalopods off west Greenland. Polar Biol 29:169-178

Publisher's note Springer Nature remains neutral with regard to jurisdictional claims in published maps and institutional affiliations. 